\title{
The site formation history of Schöningen 13II-4 (Germany): Testing different models of site formation by means of spatial analysis, spatial statistics and orientation analysis
}

\author{
Carli Peters $^{\mathrm{a}, \mathrm{b}, *}$, Thijs van Kolfschoten ${ }^{\mathrm{b}, \mathrm{c}}$

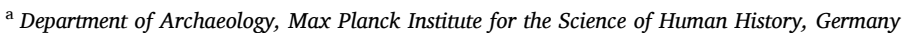 \\ ${ }^{\mathrm{b}}$ Faculty of Archaeology, Leiden University, the Netherlands \\ ${ }^{\mathrm{c}}$ Institute of Cultural Heritage, Cultural Heritage, Shandong University, 72 Binhai Highway, Qingdao, 266237, China
}

\section{A R T I C L E I N F O}

\section{Keywords:}

Spatial analysis

Orientation analysis

Site formation processes

Middle Pleistocene

\begin{abstract}
A B S T R A C T
The Lower Palaeolithic, Middle Pleistocene locality Schöningen has been a focus of archaeological research for over two decades. The locality is best-known for the discovery of wooden spears in close association with numerous butchered remains of horses and other large mammals in the Spear Horizon (Schö 13II-4), with an age of ca. $300 \mathrm{kyr}$. Several site formation models have been proposed to explain the faunal accumulation at the site: 1) single hunting event on a dried lake shore; 2) multiple hunting events in the soft mud of a lake shore; 3) deposition on an exposed delta plain; 4) geogenic displacement by hydrological processes; 5) hominin waste disposal and storage behaviour; and 6) hominin butchering activities on a frozen lake surface. Visual spatial analyses allow for the (subjective) incorporation of archaeological knowledge in the interpretation of spatial data, while spatial statistics allow for more objective and reproducible inferences about spatial patterns. The combination of the two could thus provide a vital tool in disentangling complex site formation processes. This study uses a combination of visual spatial analyses, spatial statistics and orientation analyses in order to further disentangle the site formation history of Schö 13II-4 and to assess the impact of post-depositional processes on the faunal assemblage. This study revealed the existence of intra-site and inter-species differences in spatial distribution and orientation. The results of this study are compared to the suggested site formation models for Schö 13II-4 to test which of these models is most parsimonious with the spatial distribution and orientation of the faunal assemblage. It is concluded that the previously proposed site formation models are overly simplified and cannot be used to explain the site formation history of Schö 13II-4.
\end{abstract}

\section{Introduction}

The Middle Pleistocene locality Schöningen is located in an open-cast lignite mine north-east of the German town Schöningen. The locality is best-known for the discovery of nine wooden throwing spears, a thrusting spear and a throwing stick with an age of ca. $300 \mathrm{kyr}$, found at the site Schöningen 13II-4 (Schö 13II-4) (Serangeli et al., 2015). Numerous butchered remains of horses and other large mammals were found in close association with the wooden spears (Thieme, 1997, 2005; Van Kolfschoten et al., 2015a). The fossil remains were embedded in waterlogged sediments which led to exceptionally well preserved fossil material. Furthermore, the groundwater at the Schöningen locality is exceptionally rich in calcium carbonate, which further favours the preservation of organic materials (Van Kolfschoten, 2014). The good preservation of fossil material makes Schöningen one of the key sites for understanding hominin activities and behaviour in Europe during the Middle Pleistocene.

The site formation history of Schö 13II-4 is a topic of debate and several site formation models have been proposed to explain the faunal accumulation at the site.

1) Thieme $(2005,2007)$ argues that the archaeological and faunal assemblages from Schö 13II-4 represent a single hunting event on a dried lake shore that had been preserved in situ. The presence of reddened sediments, which were interpreted as hearths, together with the large accumulation of equid remains, were the main

\footnotetext{
* Corresponding author. Department of Archaeology, Max Planck Institute for the Science of Human History, Kahlaische Straße 10, 07745, Jena, Germany.

E-mail address: peters@shh.mpg.de (C. Peters).
} 


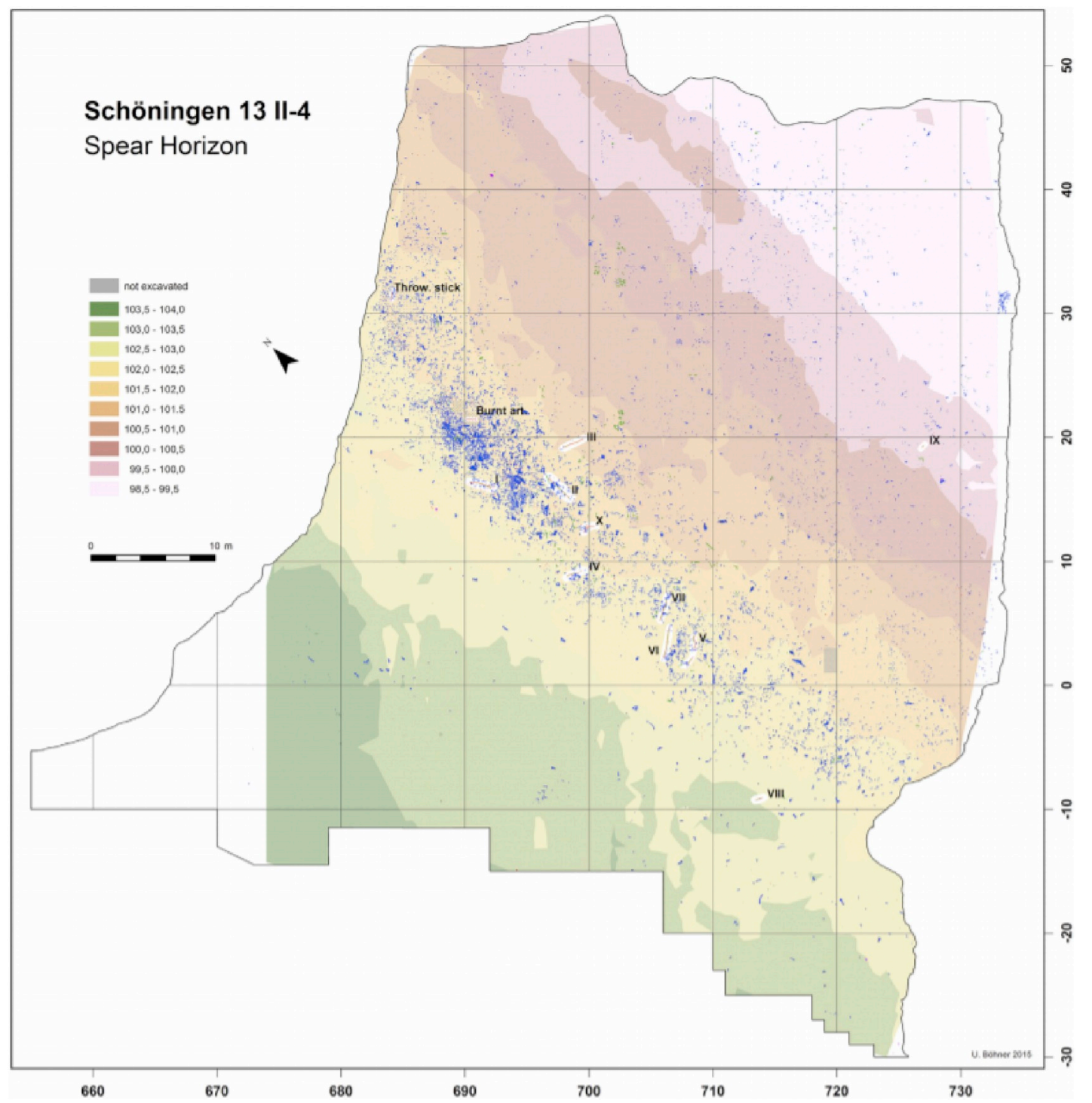

Fig. 1. Spatial distribution of all finds at Schö $13 \mathrm{II}-4$ projected on the digital elevation map of the site. Blue: faunal remains. Red: lithics. Green: wooden objects (Böhner et al., 2015). (For interpretation of the references to colour in this figure legend, the reader is referred to the Web version of this article.)

arguments on which this site formation model was based (Thieme, 2005, 2007).

2) Voormolen (2008) argues that the faunal assemblage represents multiple hunting events in the soft mud of the lake shore. The low representation of specific skeletal elements in the faunal assemblage is interpreted as the result of hominin selection rather than of hydrological processes, thereby suggesting that the faunal assemblage is located in a primary context (Voormolen, 2008). Carbon and oxygen isotopic analyses (Julien et al., 2015) as well as tooth wear analysis on horse remains (Rivals et al., 2015) support the existence of multiple accumulation events.

3) Lang et al. (2012) argue that the faunal assemblage was deposited on an exposed delta plain which was subsequently submerged by a lake-level rise. The main argument proposed for this site formation model is the good and complete preservation of the wooden spears (Lang et al., 2012).

4) Stahlschmidt et al. (2015) conducted micromorphological analyses combined with organic petrology and Fourier transform infrared analysis to examine the depositional environments of Schö 13II-4. This study suggests that the sediments of Schö 13II-4 were deposited in a mosaic swamp environment while being permanently covered in water (Stahlschmidt et al., 2015), which contradicts the other site formation models. Therefore three alternative site formation models have been proposed by Stahlschmidt et al. (2015):

a. The geogenic displacement of the faunal assemblage by hydrological processes from a hominin butchery site in the vicinity of the locality into the lacustrine sediments of Schö 13II-4. It is argued that the faunal remains were transported by a low-energy process over a short distance (Stahlschmidt et al., 2015).

b. The anthropogenic accumulation of faunal remains as a result of hominin waste disposal and storage behaviour (Stahlschmidt et al., 2015). The subaqueous storage of meat has been proven to be a good method for meat preservation as subaqueous environments have favourable conditions in which meat can be preserved for several months (Bethke et al., 2018; Fisher, 2009; Speth, 2017).

c. Hominin butchering activities on a frozen lake surface (Stahlschmidt et al., 2015). The use of frozen lake and river surfaces for animal butchering is common in northern latitudes and has been recorded in ethnography (Landals, 1990). The animals are trapped on the slippery surface of the frozen water surface after which the animals are butchered.

In this paper, we present visual spatial analyses, spatial statistics and 


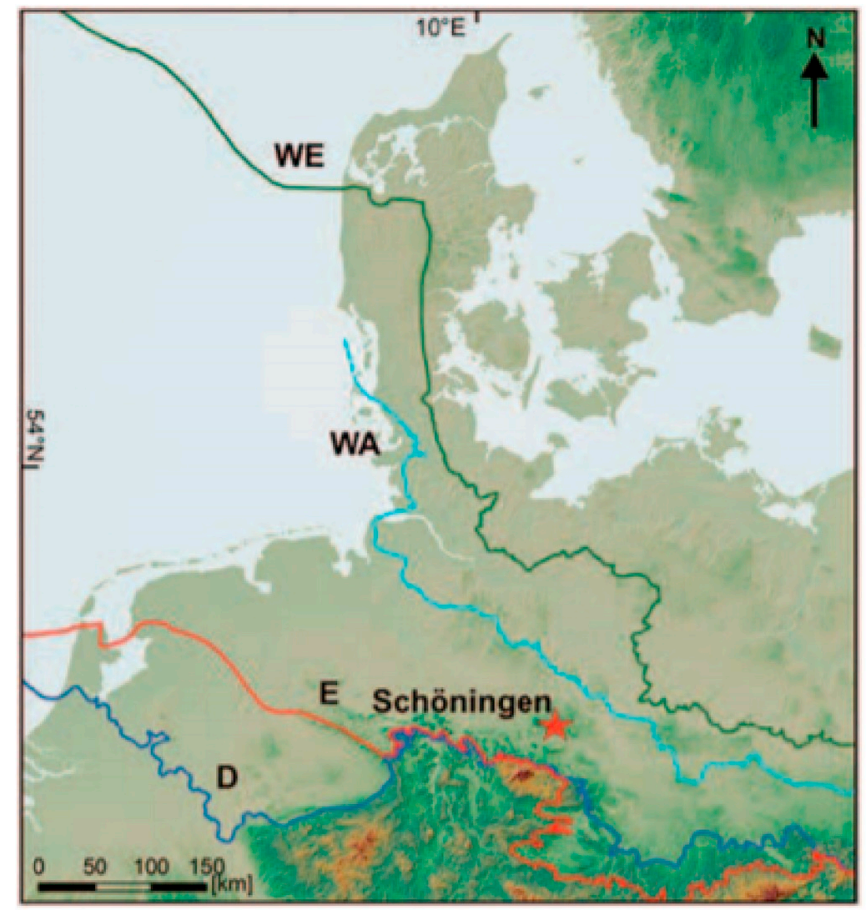

Fig. 2. Maximum extent of the Middle and Late Pleistocene Scandinavian ice sheets. E: Elsterian glaciation; D: Saalian-Drenthe glaciation; WA: SaalianWacke glaciation; WE: Weichselian glaciation (Lang et al., 2012, in Van Kolfschoten, 2012).

orientation analyses of the Schö 13II-4 faunal assemblage to test the previously proposed site formation models of the Schö 13II-4 site. An initial spatial analysis of the Schö 13II-4 site was performed by Böhner et al. (2015). This study presented a digital elevation model and spatial distribution map of the site (Fig. 1) as well as some preliminary kernel density analyses and orientation analyses. However, spatial statistics were not used extensively and detailed orientation analyses are missing in this study.

Spatial distribution maps are often used as primary tools to identify and analyse spatial patterning in the archaeological record. However, archaeological conclusions based on such maps are often subjective and not reproducible (Bevan et al., 2013). Spatial statistics allows one to move beyond these issues of subjectivity in order to make more reliable inferences based on spatial patterns. The use of spatial statistics to study site formation processes is a relatively recent development and only a limited number of studies have been published in which this approach is used (Benito-Calvo and de la Torre, 2011; Boschian and Saccà, 2010; Domínguez-Rodrigo et al., 2014; Giusti and Arzarello, 2016; Giusti et al., 2018; Romagnoli and Vaquero, 2016; Sánchez-Romero et al., 2016; Thacher et al., 2017). Even though spatial statistics allow for more objectivity, the visualization of spatial patterns remains useful for archaeological research, since it allows the incorporation of archaeological knowledge in the interpretation of spatial data (Wansleeben, 2017). The combination of visual spatial analysis, spatial statistics and orientation analyses could thus be a vital tool in disentangling complex site formation processes, and thus be essential to make reliable inferences about hominin activities and behaviour at Schö 13II-4.

\section{Schöningen 13II-4}

\subsection{Geologic setting and stratigraphic position}

The lignite quarry, with the Lower Palaeolithic site Schö 13 II-4, is located in a sedimentary basin on the flanks of a salt dome (Voormolen, 2008). The region has been covered by Scandinavian ice sheets twice (Fig. 2); once during the Elsterian glaciation and once during the Saalian-Drenthe glaciation (Stahlschmidt et al., 2015).

The base of the Quaternary sedimentary sequence consists of Elsterian glacial till and glaciofluvial sands. These sediments are erosively overlain by six river channels (Schö I-VI), which represent a series of interglacial/glacial cycles (Fig. 3) (Thieme, 2005). Channels I-III date

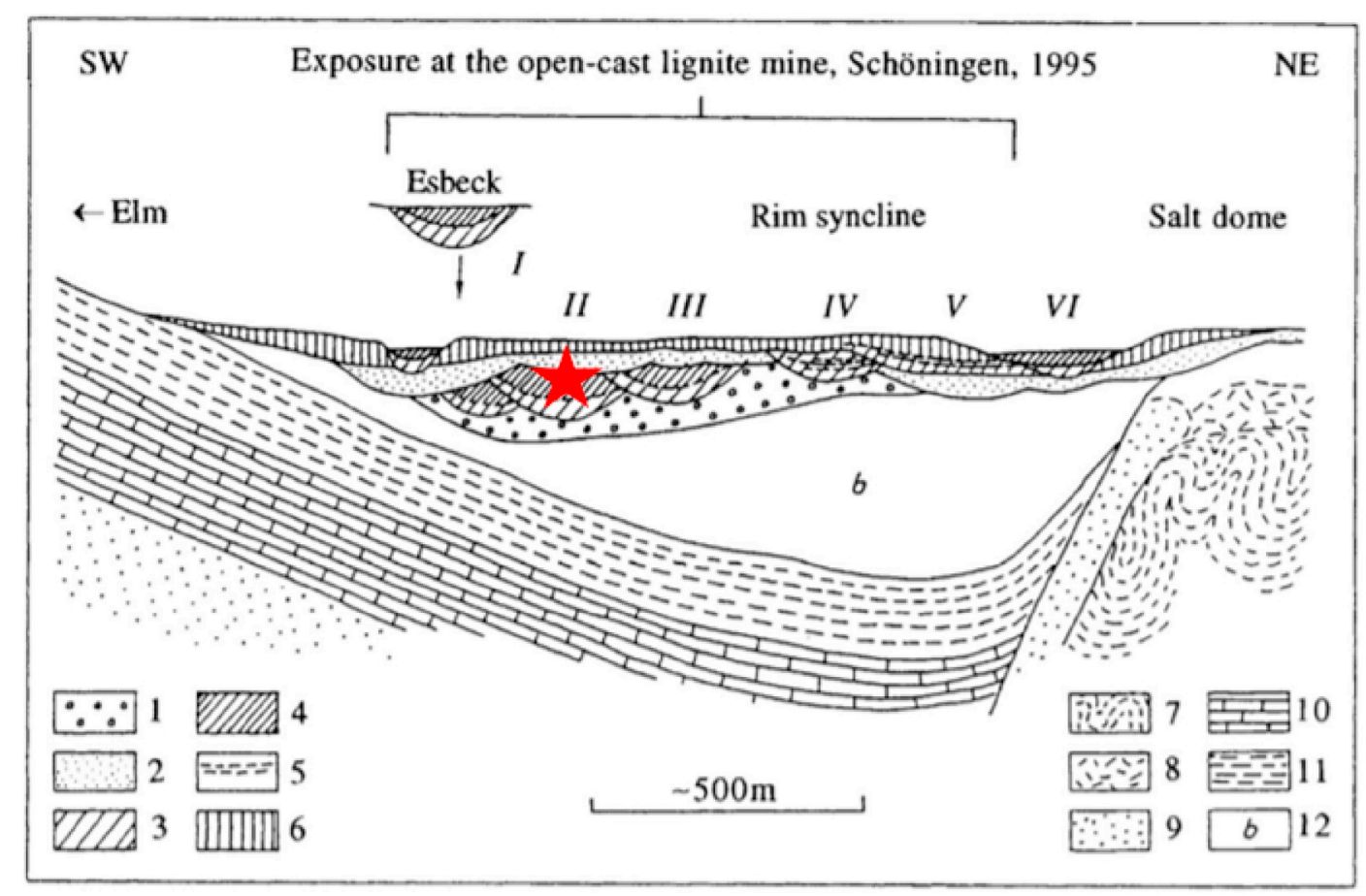

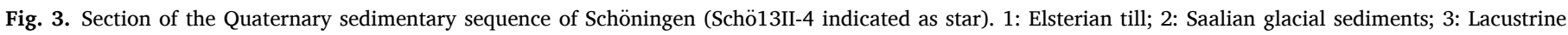

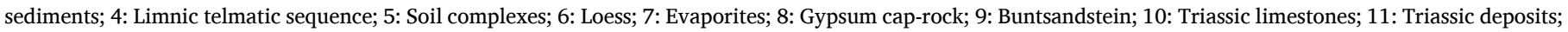
12: Palaeogene deposits (after: Van Kolfschoten, 2014). 
to the period between the Elsterian and Saalian (Drenthe) glaciations (Urban, 2007). Channels IV-VI overlie the Saalian deposits and postdate the Saalian (Thieme, 1997).

The Schö II channel is filled with sediments dating to the locally defined Reinsdorf Interglacial and the subsequent Fuhne cold stage. The depositional sequence of the Schö II channel consists of five distinct depositional cycles of organic muds and peats (levels 1-5) (Thieme, 2005). These cycles represent the rising and falling of lake levels (Voormolen, 2008). Mud and peat deposits, representing the interglacial maximum of the Reinsdorf Interglacial are located at the base of the sequence (level 1). Level 2 has been deposited during a stadial phase and level 3 during an interstadial phase. The upper levels (level 4 and 5) represent more temperate phases. Frost wedges occurring between these levels mark the beginning of periglacial conditions (Van Kolfschoten, 2012).

Three spatial zones are distinguished at the Schö 13II-4 site: the palaeolake area, the accumulation zone and the lake shore. The accumulation zone represents the area in which the majority of the fossil material is situated. This area may or may not have been under water at the time of deposition. The palaeolake represents the northern part of the site which was almost certainly covered by water at the time of deposition. The lake shore represents the southern part of the site which was not covered by water.

\subsection{Environmental setting}

Excavations at Schö 13II-4 have yielded over 12,000 faunal remains. Equus mosbachensis is the dominant species in the faunal assemblage (Van Kolfschoten et al., 2015a). The mammalian species from Schö 13II-4 consist of a combination of forest dwellers (e.g. Stephanorhinus kirchbergensis) and steppe dwellers (e.g. Stephanorhinus hemitoechus and Bison priscus) as well as aquatic species (e.g. Castor fiber). The mammalian taxa recovered at the site are indicative of a mixed landscape in the vicinity of a lake or stream; an area in which forested areas and open grasslands alternate (Van Kolfschoten, 2014). Micromorphological analysis indicate that Schö $13 \mathrm{II}-4$ was at least partly covered by a permanent water body (Stahlschmidt et al., 2015).

\subsection{Archaeology}

The lithic assemblage of Schö 13II-4 consists of nearly 1500 flint artefacts, dominated by retouched scrapers, points and retouching debris (Thieme, 2005). Soft hammer techniques were used to re-sharpen the flint tools as evidenced by the presence of bone retouchers (Van Kolfschoten et al., 2015b).

The faunal assemblage of Schö 13II-4 consists of natural background fauna together with the remains of butchered animals (Serangeli et al., 2018). The effect of (post-)depositional processes such as fluvial transport (rolling) as well as bone weathering is limited just as the occurrence of traces of carnivore gnawing on mammal bones (Van Kolfschoten et al., 2015a). The majority of carnivore gnawing marks originate from large carnivores in the size-range of wolves and sabre-toothed cats (Starkovich and Conard, 2015).

Hominin activities at Schö 13II-4 are evidenced by the presence of hominin modification marks on $16 \%$ of the faunal assemblage. These modification marks are related to a variety of butchering activities, including skinning, defleshing, disarticulation and marrow extraction. Furthermore, percussion damage indicates that approximately 100 bones were used as knapping tools, smoothened-tip tools or metapodial hammers. In total, cut marks were identified on $15 \%$ of horse bones and $11,8 \%$ of horse bones show percussion damage. Hominin modification marks have also been identified on cervid remains, bovid remains and on the humerus of a sabre toothed cat, but evidence of hominin modification on these species is more limited (Van Kolfschoten et al., 2015a, 2015b; Voormolen, 2008).

\section{Expected spatial distribution patterns}

Each site formation model proposed for Schö 13II-4 would lead to different spatial signatures and orientation patterns. In the following section a series of expectations is formulated for each site formation model.

\subsection{Single and multiple hunting and butchering events on a lake shore}

The site formation models regarding single or multiple hunting and butchering events on a lake shore are expected to result in similar spatial distribution and orientation patterns of faunal remains. Therefore, the expected patterns for these models have been grouped together. The in situ preservation of single or multiple hunting and butchering events on a lake shore would lead to the close spatial association of several horse carcasses. A clustering of equid fossil material in a single area of the site, and, more importantly, of equid remains with evidence of hominin modification is expected. Furthermore, equid remains are expected to follow a random orientation pattern, resulting from various hominin and carnivore activities (Uthmeier and Chabai, 2018). Finally, it is expected that the background fauna has a different spatial signature compared to the equid remains, since these remains would likely have been subjected to hydrological processes connected to the nearby palaeolake.

\subsection{Accumulation on an exposed delta plain}

The deposition of the faunal assemblage on an exposed delta plain followed by a lake-level rise is expected to lead to small movements and the re-orientation of fossil material following the burial of the fossil material. The faunal remains would be concentrated in a single area of the site which represents (the edges of) the exposed delta plain. Furthermore, lake level fluctuations result in the existence of relict shorelines corresponding to a certain lake level. The existence of relict shore lines would be associated with low density clusters of fossil material located in the lake bed.

\subsection{Geogenic displacement by hydrological processes}

The geogenic displacement of the faunal assemblage by hydrological processes implies that the all bones have been subjected to a similar level of reworking and transportation. No difference in spatial distribution and orientation should thus be observed between equids and the natural background fauna and anatomically connected units are expected to be absent from the fossil assemblage. High-energy processes transport bones over long distances and result in the absence of small-sized skeletal elements, while low-energy processes generally transport bones over shorter distances and do not result in the absence of small-sized skeletal elements (Petraglia and Potts, 1994; Schick, 1984). Small-sized skeletal elements are thus expected to be present in the faunal assemblage. Furthermore, elongated bone fragments in the palaeolake and the accumulation zone are expected to have a preferential orientation resulting from hydrological processes (Kreutzer, 1988). In shallow waters long bones with epiphyses of different densities are generally oriented parallel to the direction of the current (Thayer Morton, 1995), while elongated bones with an equal distribution of weight are generally oriented perpendicular to the current direction (Lyman, 1994). The orientation of fossil remains on the shore is expected to be random.

\subsection{Hominin waste disposal and storage behaviour}

The accumulation of faunal material resulting from hominin waste disposal and storage behaviour is expected to lead to the spatial clustering of fossil material along the margins of the palaeolake in the accumulation zone. A small number of faunal remains could be located further into the palaeolake as bones are tossed into the water body 
Table 1

Schö 13II-4. Number of faunal remains (NISP) per taxon included in this research.

\begin{tabular}{ll}
\hline Taxon & Number of faunal remains (NISP) \\
\hline Order Carnivora & \\
Homotherium latidens & 1 \\
Canis lupus & 3 \\
Vulpes vulpes & 1 \\
Order Proboscidea & \\
Palaeoloxodon antiquus & 1 \\
Proboscidea indet. & 3 \\
Order Perissodactyla & \\
Equus mosbachensis & 3958 \\
Equus hydruntinus & 2 \\
Stephanorhinus kirchbergensis & 1 \\
Stephanorhinus hemitoechus & 1 \\
Rhinocerotidae indet. & 4 \\
Order Artiodactyla & \\
Cervus elaphus & 143 \\
Megaloceros giganteus & 2 \\
Cervidae indet. & 24 \\
Bos primigenius & 19 \\
Bison priscus & 23 \\
Bos/Bison & 108 \\
\hline
\end{tabular}

(Speth, 2017). Elongated bone fragments in the accumulation zone are expected to be randomly oriented following storage or disposal activity. Finally, it is expected that the natural background fauna has a different spatial signature and orientation compared to the equid remains.

\subsection{Frozen lake surface}

The use of frozen lake and river surfaces for animal butchering is common in northern latitudes and has been recorded in ethnography (Landals, 1990). The animals are trapped on the slippery surface of the frozen water surface after which the animals are butchered. When the ice melts, the faunal remains and lithics on the ice sink to the bottom of the lake where they are scattered by fluvial processes and preserved (Fisher, 2009; Landals, 1990; Speth, 2017). This process results in the absence of dense bone accumulations. Instead, the faunal material is expected to be randomly distributed across the site in low-density bone clusters. Articulated skeletal elements are also expected to be absent from the faunal assemblage. Furthermore, after fossil material sank to the bottom of the lake, minor reworking by hydrological processes may have resulted in the preferential orientation of elongated bones.

\section{Material and methods}

\subsection{Material}

The spatial data from the faunal material from Schö 13II-4 was recorded during the excavations. The spatial data consists of the $\mathrm{X}$ and $\mathrm{Y}$ coordinates of the faunal material. A total of 12,023 faunal remains from Schö 13II-4, excavated prior to 2015, have been included in the analyses. Table 1 gives an overview of the number of identified faunal remains per taxon included in the research. The recording of spatial data allows for the construction of spatial distribution maps and subsequent spatial analyses. Orientation data were not recorded during the excavations. However, detailed drawings of every $1 \times 1 \mathrm{~m}$ square showing the position and orientation of all the finds larger than $5 \mathrm{~cm}$, have been made in the field during the excavation. The orientation data of the finds included in this study has been retrieved from combined scans of the field drawings and the orientation of a total of 2658 faunal remains were recorded manually.

\subsection{Spatial analysis}

The spatial data from the Schö 13II-4 faunal material has been integrated in two GIS software packages. ArcMap 10.2.2 software (ESRI, 2014) and QGIS 2.16.2 software (QGIS Development Team, 2009) were used for the visualization of spatial point data and to conduct subsequent spatial analyses. The first step in the spatial analysis is to identify and characterise distribution patterns within the faunal assemblage. Ripley's K function (Ripley, 1976) is a statistical point pattern analysis that has been used to statistically assess the level of spatial clustering of the faunal remains. Following the identification of clusters in the spatial point data, the number, location and intensity of the clusters need to be defined. For this study, kernel density analyses have been conducted with the Kernel Density Tool in ArcMap 10.2.2 (ESRI, 2014) to identify the number, location and density of bone clusters. Search radii of 5 and $10 \mathrm{~m}$ have been implemented. Furthermore, kernel density analyses were used to present a visualization of the intensity of the bone clusters.

\subsection{Orientation analysis}

Skeletal elements are initially positioned in an anatomical context, which could potentially influence the results of the orientation analyses. However, there is a clear disarticulation of skeletal elements at Schö 13II-4 (Voormolen, 2008). Even though it is not possible to fully exclude the possibility that the original orientation of the skeletal elements in their anatomical position has influenced the orientation of the fossil material in some cases, the process of disarticulation indicates that the orientation of the vast majority of the fossil remains were not influenced by their original anatomical position. Therefore, the original anatomical position of the skeletal elements was not included as a parameter for the orientation analysis.

The orientation analysis consisted of three steps. The first step was to collect orientation data for all elongated bones from Schö 13II-4. The orientation data has been manually recorded from the excavation plan. The A-axis was estimated by measuring the maximum length of each polygon. The B-axis was the measurement of the maximum length of the segment perpendicular to the A-axis. The values of the A- and B-axis were then used to calculate $\mathrm{I}_{\mathrm{E}}$ (= A-axis/B-axis), a measure of elongation. Lastly, the azimuth of the bone was estimated by measuring the angle between the A-axis of the bone and the Y-axis of the excavation map (Benito-Calvo and de la Torre, 2011). It is important to take into account that the manual recording of orientation values may be biased due to the human tendency to round values (García-Moreno et al., 2016) and due to the possible lack of accuracy from archaeological site maps (Domínguez-Rodrigo et al., 2012). For this study, the Y-axis used for the measurements is the $\mathrm{Y}$-axis of the excavation grid, with $0^{\circ}$ at the top of the map. Fossil remains with an $\mathrm{I}_{\mathrm{E}}>1.6$ were classified as elongated bones. Fossil remains with an $\mathrm{I}_{\mathrm{E}}<1.6(\mathrm{n}=45)$ were excluded from subsequent analyses.

Subsequent to data collection, the orientation data was visually summarized in rose diagrams. An online program for the construction of rose diagrams (Yong Technology Inc, 2014) was utilized to produce the rose diagrams. Rayleigh's test, Kuiper's test (Kuiper, 1960), the Watson test (Watson, 1961) and the Rao spacing test (Rao, 1969) were performed to assess the uniformity of the orientation data and to identify the presence of uniform, uni-modal and multi-modal orientations. A uniform orientation is the random distribution of data points. An uni-modal orientation is the distribution of data points in a single axis of orientation. A multi-modal orientation is the distribution of data points in multiple axes of orientation. The circular statistical tests were conducted in R 3.4.2 (R Core Team, 2013) with the "rayleigh.test", "kuiper. test", "watson.test" and "rao.spacing.test" functions from the R circular library (Agostinelli and Lund, 2017).

\section{Results}

\subsection{Spatial analysis}

Ripley's K analyses of individual taxa have shown that the equid, 

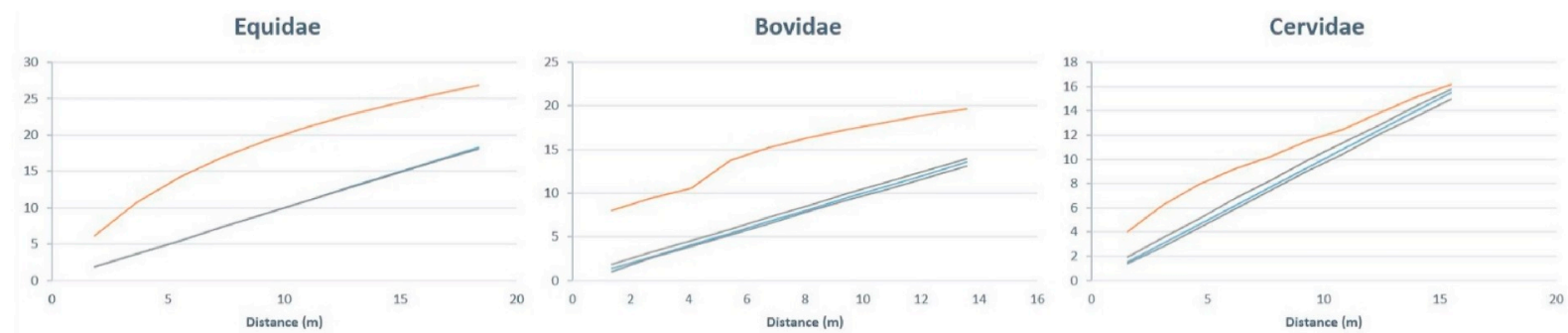

Fig. 4. Ripley's $\mathrm{K}$ analysis for equids $(\mathrm{n}=3960)$, bovids $(\mathrm{n}=150)$ and cervids $(\mathrm{n}=169)$. Blue: expected K-value. Orange: observed K-value. Grey: confidence envelope. (For interpretation of the references to colour in this figure legend, the reader is referred to the Web version of this article.)

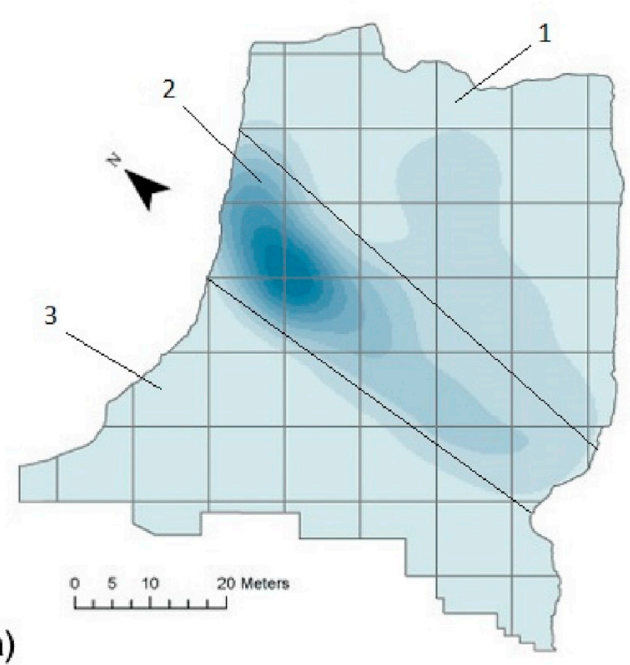

a)

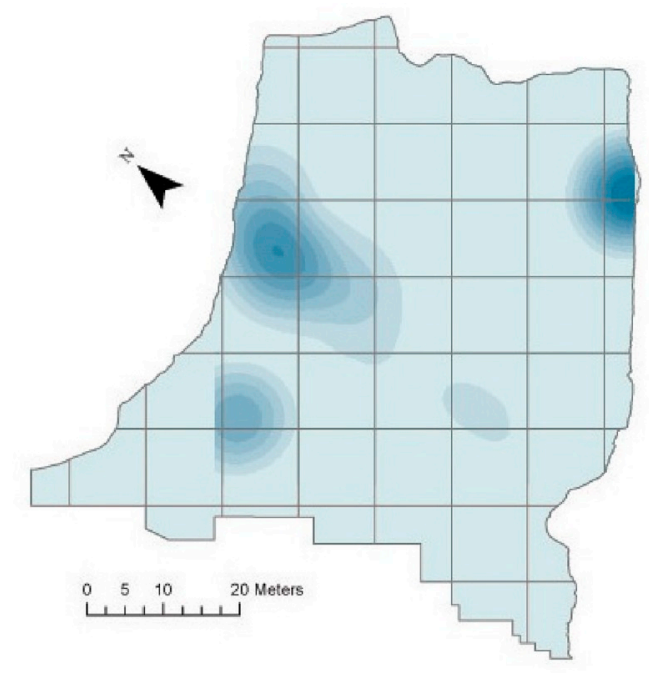

c)
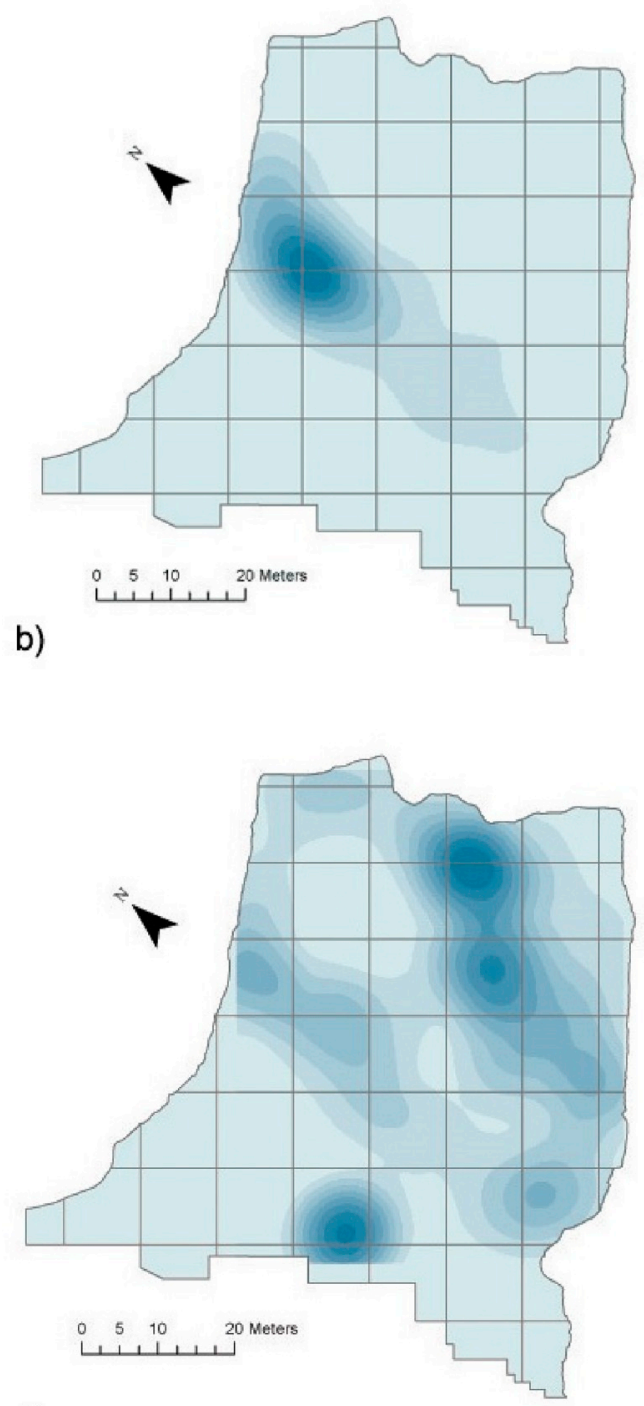

d)

Fig. 5. Kernel density of a) all fossil remains; b) equids ( $\mathrm{n}=3960)$; $\mathrm{c}$ ) bovids $(\mathrm{n}=150)$; and $\mathrm{d})$ cervids $(\mathrm{n}=169)$. 1: palaeolake; 2: accumulation zone; 3: lake shore. Bandwidth: $10 \mathrm{~m}$. Raster: $10 \times 10 \mathrm{~m}$.

bovid and cervid remains are clustered for all distance bands (Fig. 4). No reliable Ripley's K analyses could be conducted for carnivores, proboscides and rhinoceroses due to the limited sample sizes for these taxa.

Kernel density analysis confirmed that the highest density of faunal remains is located in the northern part of the accumulation zone (Fig. 5). Inter-species differences in spatial distribution have been observed. Equid remains are concentrated in a single, high-density cluster in the northern part of the accumulation zone. Four clusters of bovid remains have been identified. The densest cluster is located in the palaeolake, two clusters are located in the accumulation zone and the final cluster is situated on the lake shore. The majority of the cervid remains is located in the palaeolake. Two less dense bone concentrations have been identified in the accumulation zone, and one cluster is located on the lake shore. Proboscides, rhinoceroses and carnivores are only represented by isolated finds which are distributed randomly throughout the site.

Kernel density analyses of equid remains with cut marks and impact 

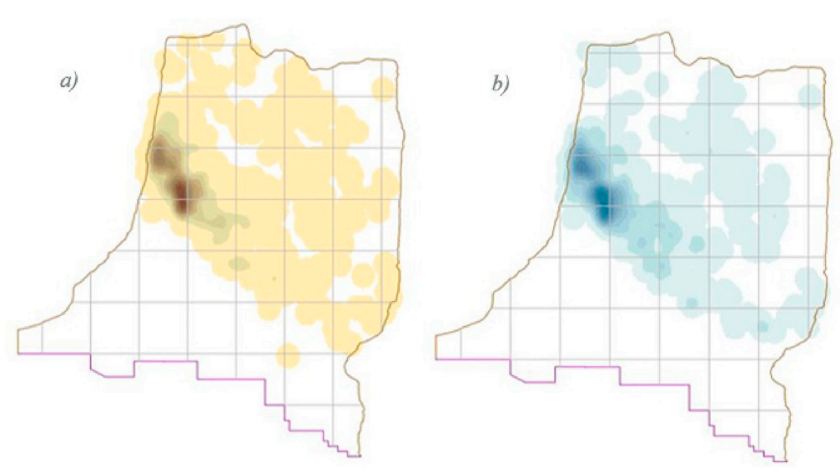

Fig. 6. Kernel density of a) equid remains with cut marks; and b) equid remains with impact marks. 1: Bandwidth: $5 \mathrm{~m}$. Raster: $10 \times 10 \mathrm{~m}$ (graphics: M. Wansleeben).

marks (Fig. 6) show similar patterns of distribution with the highest concentration of fossil remains located in the northern part of the accumulation zone.

\subsection{Orientation analysis}

Faunal remains located in the palaeolake and accumulation zone are preferentially oriented in two main directions: NW-SE and NE-SW (Fig. 7). These orientation patterns are statistically significant (Table 2). The faunal remains on the lake shore show no evidence, both visually and statistically, of a preferential orientation. These faunal remains have a uniform distribution.
Inter-species differences in orientation were also observed. Equid remains are preferentially oriented similar to faunal remains in the palaeolake and accumulation zone with two main orientations. These orientations have been proven to be statistically significant. The bovid remains appear to have an uni-modal distribution, in which the main axis of orientation is N-S. However, Rayleigh's test has rejected the existence of an uni-modal distribution. The cervid remains appear to have an uni-modal distribution with a main axis of orientation NW-SE. This orientation has also been rejected by Rayleigh's test. The discrepancy between the visualization of orientation data in rose diagrams and statistical tests may be connected to a small sample size.

Table 2

Schö 13II-4. Results of circular statistical test results. V: values that reject the null hypothesis of circular uniformity.

\begin{tabular}{lllll}
\hline & $\begin{array}{l}\text { Rayleigh } \\
\text { test }\end{array}$ & $\begin{array}{l}\text { Kuiper } \\
\text { test }\end{array}$ & $\begin{array}{l}\text { Watson } \\
\text { test }\end{array}$ & $\begin{array}{l}\text { Rao spacing } \\
\text { test }\end{array}$ \\
\hline $\begin{array}{l}\text { Complete faunal } \\
\text { assemblage }\end{array}$ & $\mathrm{V}$ & $\mathrm{V}$ & $\mathrm{V}$ & $\mathrm{V}$ \\
$\begin{array}{l}\text { Palaeolake } \\
\text { Accumulation zone }\end{array}$ & - & $\mathrm{V}$ & $\mathrm{V}$ & $\mathrm{V}$ \\
Lake shore & - & $\mathrm{V}$ & $\mathrm{V}$ & $\mathrm{V}$ \\
Equids & $\mathrm{V}$ & - & - & - \\
Equids in palaeolake & - & $\mathrm{V}$ & $\mathrm{V}$ & $\mathrm{V}$ \\
Equids in accumulation & - & - & - & $\mathrm{V}$ \\
$\quad$ zone & & $\mathrm{V}$ & - & $\mathrm{V}$ \\
Equids on lake shore & - & & & \\
Bovids & - & - & - & $\mathrm{V}$ \\
Cervids & - & - & - & - \\
\hline
\end{tabular}

a)
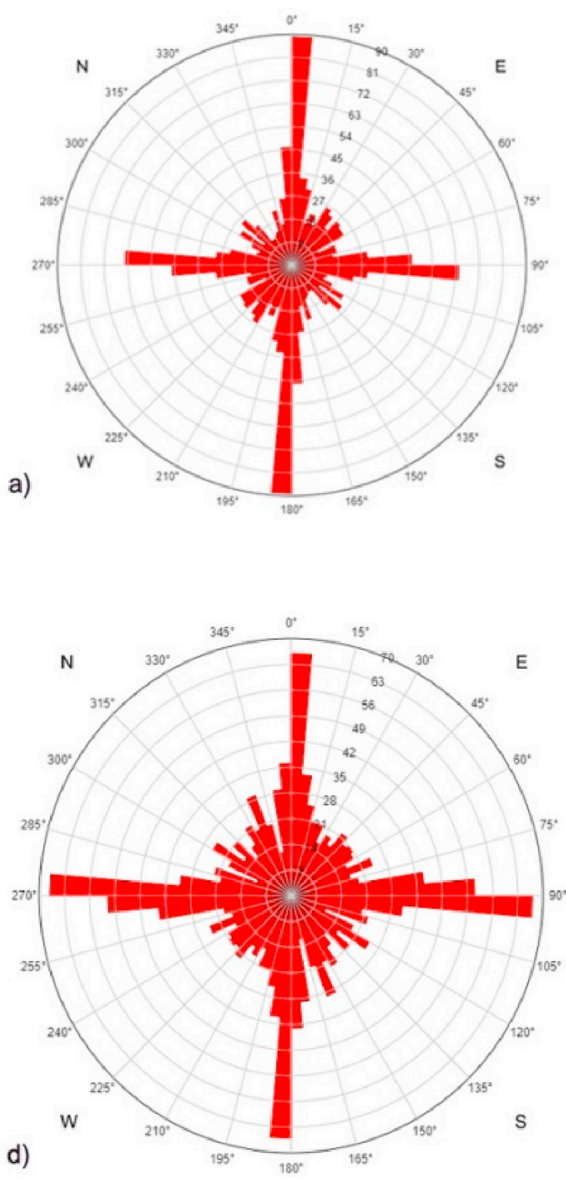

b)
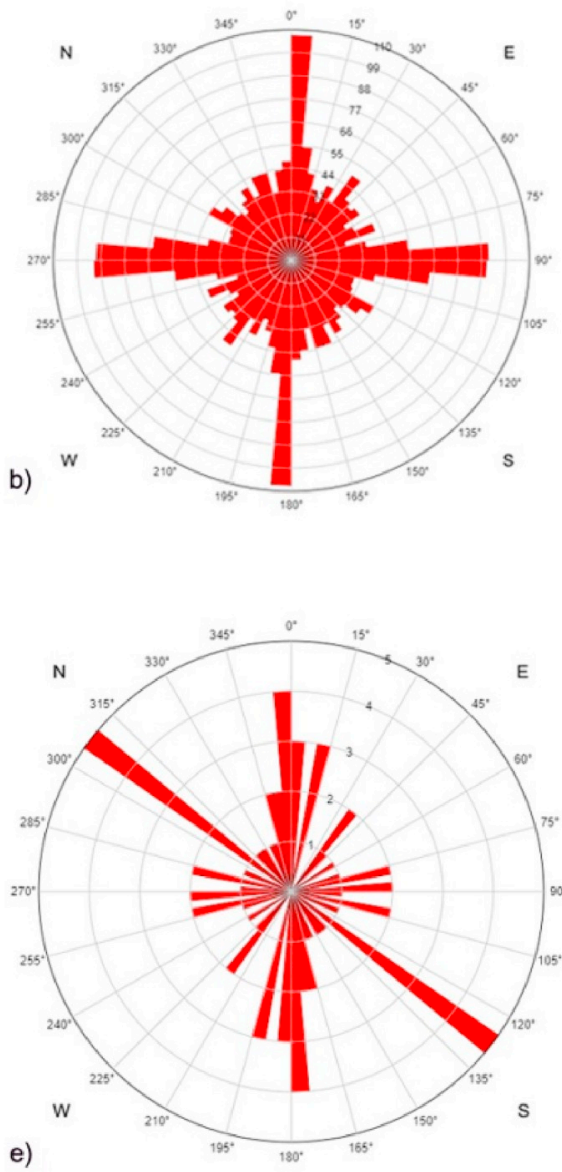
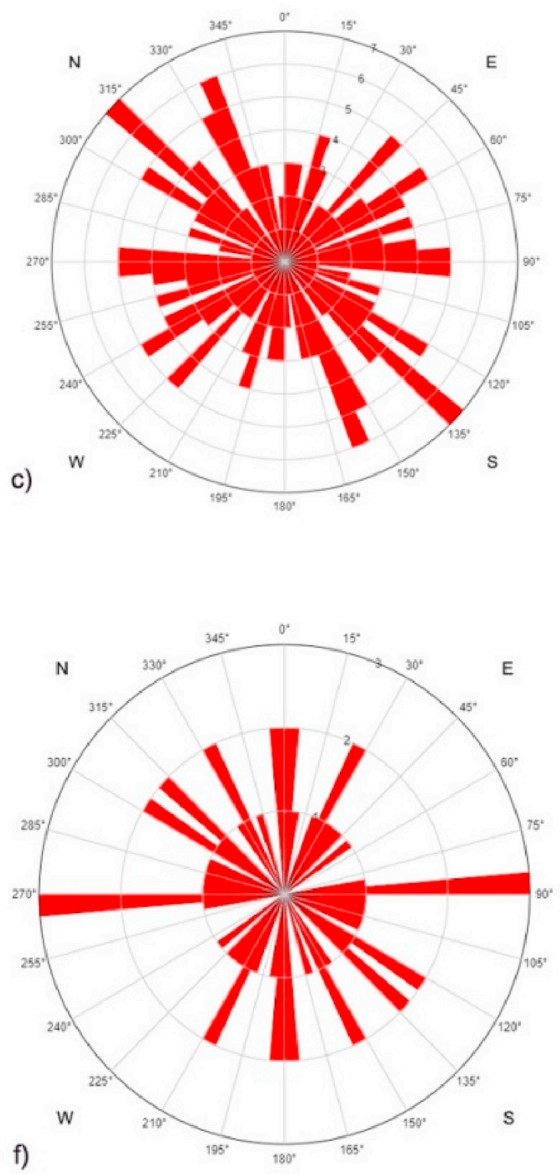

Fig. 7. Rose diagrams presenting the orientation of fossil remains: a) palaeolake $(\mathrm{n}=888) ; \mathrm{b})$ accumulation zone $(\mathrm{n}=1556)$; $\mathrm{c})$ lake shore $(\mathrm{n}=112)$; $)$ equids $(\mathrm{n}=$ 896); e) bovids ( $\mathrm{n}=37)$; and $\mathrm{f}$ ) cervids $(\mathrm{n}=30)$. 
Table 3

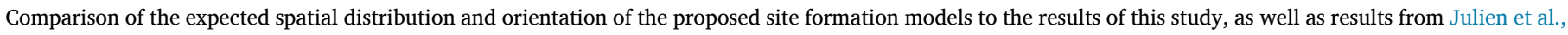
(2015), Rivals et al., (2015) and Stahlschmidt et al., (2015). X represents instances in which the expectation corresponds to the results.

\begin{tabular}{|c|c|c|c|c|c|c|}
\hline & $\begin{array}{l}\text { Single hunting and } \\
\text { butchering event }\end{array}$ & $\begin{array}{l}\text { Multiple hunting and } \\
\text { butchering events }\end{array}$ & $\begin{array}{l}\text { Exposed delta } \\
\text { plain }\end{array}$ & $\begin{array}{l}\text { Geogenic } \\
\text { displacement }\end{array}$ & $\begin{array}{l}\text { Hominin waste disposal/ } \\
\text { storage behaviour }\end{array}$ & $\begin{array}{l}\text { Frozen lake } \\
\text { surface }\end{array}$ \\
\hline \multicolumn{7}{|l|}{ Spatial distribution } \\
\hline - Equids & $\mathrm{X}$ & $\mathrm{X}$ & $\mathrm{X}$ & & $\mathrm{X}$ & \\
\hline - Natural background fauna & $\mathrm{X}$ & $\mathrm{X}$ & $\mathrm{X}$ & & $\mathrm{X}$ & \\
\hline \multicolumn{7}{|l|}{ Orientation } \\
\hline - Equids & & & & $\mathrm{X}$ & & $\mathrm{X}$ \\
\hline - Natural background fauna & & & & $\mathrm{X}$ & $\mathrm{x}$ & \\
\hline - Accumulation zone & & & & $\mathrm{X}$ & & \\
\hline $\begin{array}{l}\text { Depositional environment ( } \\
\text { Stahlschmidt et al., 2015) }\end{array}$ & & & & $\mathrm{X}$ & $\mathrm{X}$ & $\mathrm{X}$ \\
\hline $\begin{array}{l}\text { Seasonality (Julien et al., 2015; } \\
\text { Rivals et al., 2015) }\end{array}$ & & $\mathrm{X}$ & $\mathrm{X}$ & & $\mathrm{X}$ & \\
\hline
\end{tabular}

\section{Discussion and conclusion}

The results of the spatial analyses indicate that there are inter-species differences in distribution, with equids densely clustered in the accumulation zone. Opposed to this, the orientation of the faunal remains suggests fluvial reworking in this area of the site. This implies that the faunal material has not been transported by fluvial processes, but is more likely to have been rearranged. In order to identify which site formation model is most parsimonious with the collected data for this study, the results have been compared to the expected results of each site formation model (Table 3).

1) A single or multiple hunting and butchering event could lead to the close spatial association of multiple butchered horse carcasses. The spatial clustering of equid remains in the accumulation zone thus confirms the expectation for a single or multiple hunting and butchering event model. However, the preferential orientation of equid remains, with the existence of two perpendicular axes of orientation, is distinctive of fluvially reworked assemblages. The preferential orientation of equid remains thus contradicts the single and multiple hunting and butchering events models. The permanent water coverage of the Schö 13II-4 site (Stahlschmidt et al., 2015) is also not compatible with the single and multiple hunting and butchering event models.

2) Inter-species differences in spatial distribution have been observed. The displacement of fossil material by hydrological processes implies that all bones have been subjected to a similar level of reworking and transportation. The discrepancy between the spatial distribution of equid remains and the spatial distribution of remains of other taxa is thus not congruent with the expectations for the geogenic displacement model. Several associated skeletal elements from equids as well as a partial skeleton have been revealed in the northern part of the accumulation zone. Furthermore, associated leg and foot bones from red deer were identified (Van Kolfschoten et al., 2015a), which further disproves the geogenic displacement model.

3) The spatial clustering of faunal remains in the accumulation zone and the existence of multiple accumulation events at Schö 13II-4 is congruent with the hominin waste disposal and storage behaviour model. The exposed delta plain model and hominin waste disposal and storage behaviour model imply that the fossil material was not transported by fluvial action. Evidence of preferential orientation of the Schö 13II-4 faunal assemblage thus invalidates these models.

4) The use of frozen lake and river surfaces for animal butchering is expected to result in the absence of dense bone accumulations. The high-density accumulation of equid remains in the accumulation zone is thus opposite to the spatial distribution that would be expected for the frozen lake surface model. Furthermore, observed variability in carbon and oxygen isotope values of the Schö 13II-4 horse remains (Julien et al., 2015) and variation in equid tooth microwear patterns (Rivals et al., 2015) indicate different seasons of death for the sampled equids.

Summarizing it can be stated that the site formation history of Schö 13II-4 consists of a complex web of anthropogenic activities and natural processes. The previously proposed site formation models are thus overly simplified and cannot be used to explain the site formation history of Schö 13II-4. Instead, a combination of several site formation models provides a better approximation of the site formation history. An alternative site formation model that draws upon a couple of the previously proposed site formation models is thus suggested. The spatial and orientation data implies that the equid assemblage consists of a mix of anthropogenically accumulated remains and natural background fauna. The anthropogenically accumulated remains, the majority of which are equids, possibly result from multiple episodes of hominin waste disposal and storage behaviour. The natural background fauna, including equids, bovids and cervids, has been subjected to low-energy hydrological processes in a lacustrine environment. The bi-modal nature of the orientation data suggests that the faunal assemblage has been deposited along the margins of a palaeolake.

The findings presented in this study contribute to our understanding of the complex formation processes that shaped the Schö 13II-4 site. Our results support the findings of the micromorphology study by Stahlschmidt et al. (2015). The faunal material was likely deposited in place and was covered by water at the time of deposition or shortly after. This resulted in the rearrangement of the faunal material by fluvial processes.

\section{Declaration of competing interest}

None.

\section{Acknowledgements}

This research did not receive any specific grant from funding agencies in the public, commercial, or not-for-profit sectors. The Niedersächsiches Landesamt für Denkmalpflege (Hannover, Germany), The Ministry of Science of Lower Saxony (Germany) and the Faculty of Archaeology, Leiden University (the Netherlands) have financially supported the excavations at Schöningen during the period the material, analysed in this publication, has been collected. The authors would like to thank the professional Schöningen archaeological excavation team for their continuous enthusiasm and excellent work. M. Wansleeben (Leiden University) provided us with additional figures for which we are grateful. Finally, we would like to acknowledge the four anonymous reviewers for their helpful suggestions to improve this paper. 


\section{References}

Agostinelli, C., Lund, U., 2017. R Package 'circular': Circular Statistics, 0.4-93. https://rforge.r-project.org/projects/circular.

Benito-Calvo, A., de la Torre, I., 2011. Analysis of orientation patterns in Olduvai Bed I assemblages using GIS techniques: implications for site formation processes. J. Hum. Evol. 61, 50-60. https://doi.org/10.1016/j.jhevol.2011.02.011.

Bethke, B., Nieves-Zedeño, M., Jones, G., Pailes, M., 2018. Complementary approaches to the identification of bison processing for storage at the Kutoyis complex, Montana J. Archaeol. Sci. Rep. 17, 879-894. https://doi.org/10.1016/j.jasrep.2016.05.028.

Bevan, A., Crema, E., Li, X., Palmisano, A., 2013. Intensities, interactions, and uncertainties: some new approaches to archaeological distributions. In: Bevan, A., Lake, M. (Eds.), Computational Approaches to Archaeological Spaces. Routledge, Walnut Creeke, pp. 23-43.

Böhner, U., Serangeli, J., Richter, P., 2015. The spear Horizon: first spatial analysis of the Schöningen site 13II-4. J. Hum. Evol. 89, 202-213. https://doi.org/10.1016/j. jhevol.2015.10.001.

Boschian, G., Saccà, D., 2010. Ambiguities in human and elephant interactions? Stories of bones, sand and water from Castel di Guido (Italy). Quat. Int. 214, 3-16. https:// doi.org/10.1016/j.quaint.2009.10.016.

Domínguez-Rodrigo, M., Bunn, H.T., Pickering, T.R., Mabulla, A.Z.P., Musiba, C.M., Baquedano, E., Ashley, G.M., Diez-Martin, F., Santonja, M., Uribelarrea, D., Barba, R., Yravedra, J., Barboni, D., Arriaza, C., Gidna, A., 2012. Autochtony and orientation patterns in Olduvai Bed I: a re-examination of the status of postdepositional biasing of archaeological assemblages from FLK North (FLKN). J. Archaeol. Sci. 39, 2116-2127. https://doi.org/10.1016/j.jas.2012.02.027.

Domínguez-Rodrigo, M., Uribelarrea, D., Santonjoa, M., Bunn, H.T., García-Pérez, A., Pérez-González, A., Panera, J., Rubio-Jara, S., Mabulla, A., Baquedano, E., Yravedra, J., Diez-Martín, F., 2014. Autochtonous anisotropy of archaeological materials by the action of water: experimental and archaeological reassessment of the orientation patterns at the Olduvai sites. J. Archaeol. Sci. 41, 44-68. https://doi. org/10.1016/j.jas.2013.07.025.

ESRI, 2014. ArcGIS for Desktop. Environmental Systems Research Institute, Redlands, 10.2.2. http://www.esri.com.

Fisher, D.C., 2009. Paleobiology and extinction of proboscideans in the Great lakes region of north America. In: Haynes, G. (Ed.), American Megafaunal Extinctions at the End of the Pleistocene. Springer, Dordrecht, pp. 55-75.

García-Moreno, A., Smith, G.M., Kindler, L., Pop, E., Roebroeks, W., GaudzinskiWindheuser, S., Klinkenberg, V., 2016. Evaluating the incidence of hydrological processes during site formation through orientation analysis. A case study of the middle Palaeolithic Lakeland site Neumark-Nord 2 (Germany). J. Archaeol. Sci. Rep. 6, 82-93. https://doi.org/10.1016/j.jasrep.2016.01.023.

Giusti, D., Arzarello, M., 2016. The need for a taphonomic perspective in spatial analysis: formation processes at the Early Pleistocene site of Pirro Nord (P13), Apricena, Italy. J. Archaeol. Sci. Rep. 6, 235-249. https://doi.org/10.1016/j.jasrep.2016.06.014.

Giusti, D., Tourloukis, V., Konidaris, G.E., Thompson, N., Karkanas, P., Panagopoulou, E., Harvati, K., 2018. Beyond maps: patterns of formation processes at the middle Pleistocene open-air site of Marathousa 1, Megalopolis basin, Greece. Quat. Int. 497, 137-153. https://doi.org/10.1016/j.quaint.2018.01.041.

Julien, M.-A., Rivals, F., Serangeli, J., Bocherens, H., Conard, N.J., 2015. A new approach for deciphering between single and multiple accumulation events using intra-tooth isotopic variations: application to the Middle Pleistocene bone bed of Schöningen 13II-4. J. Hum. Evol. 89, 114-128. https://doi.org/10.1016/j.jhevol.2015.02.012.

Kreutzer, L.A., 1988. Megafaunal butchering at Lubbock lake, Texas: a taphonomic reanalysis. Quat. Res. 30, 221-231. https://doi.org/10.1016/0033-5894(88)900269.

Kuiper, N.H., 1960. Tests concerning random points on a circle. Indag. Math. 63, 38-47.

Landals, A., 1990. The Maple Leaf Site: implications for the analysis of small-scale bison kills. In: Davis, L.B., Reeves, B.O.K. (Eds.), Hunters of the Recent Past. Unwin Hyman, London, pp. 122-152.

Lang, J., Winsemann, J., Steinmetz, S., Polom, U., Pollok, L., Böhner, U., Serangeli, J., Brandes, C., Hampel, A., Winghart, S., 2012. The Pleistocene of Schöningen, Germany: a complex tunnel valley fill revealed from 3D subsurface modelling and shear wave seismics. Quat. Sci. Rev. 39, 86-105. https://doi.org/10.1016/j. quascirev.2012.02.009.

Lyman, R.L., 1994. Vertebrate Taphonomy, first ed. Cambridge University Press, Cambridge.

Petraglia, M.D., Potts, R., 1994. Water flow and the formation of Early Pleistocene Artifact sites in Olduvai Gorge, Tanzania. J. Anthropol. Archaeol. 13, 228-254. https://doi.org/10.1006/jaar.1994.1014.

QGIS Development Team, 2009. QGIS Geographic Information System. Open Source Geospatial Foundation Project, 2.16.2. http://qgis.osgeo.org.

R Core Team, 2013. R: A Language and Environment for Statistical Computing. R Foundation for Statistical Computing, Austria, 3.4.2. http://www.R-project.org/.
Rao, J.S., 1969. Some Contributions to the Analysis of Circular Data (Unpublished PhD). Indian Statistical Institute.

Ripley, B.D., 1976. The second-order analysis of stationary point processes. J. Appl. Probab. 13 (2), 255-266.

Rivals, F., Julien, M.-A., Kuitems, M., Van Kolfschoten, T., Serangeli, J., Drucker, D.G., Bocherens, H., Conard, N.J., 2015. Investigation of equid paleodiet from Schöningen 13II-4 through dental wear and isotopic analyses: archaeological implications. J. Hum. Evol. 89, 129-137. https://doi.org/10.1016/j.jhevol.2014.04.002.

Romagnoli, F., Vaquero, M., 2016. Quantitative stone tools intra-site point and orientation patterns of a Middle Palaeolithic living floor: a GIS multi-scalar spatial and temporal approach. Quartar 63, 47-60. https://doi.org/10.7485/QU63_3.

Sánchez-Romero, L., Benito-Calvo, A., Pérez-González, A., Santonja, M., 2016. Assessment of accumulation processes at the middle Pleistocene site of Ambrona (Soria, Spain). Density and orientation patterns in spatial datasets derived from excavations conducted from the 1960s to the present. PLoS One 11 (12), e0167595. https://doi.org/10.1371/journal.pone.0167595.

Schick, K.D., 1984. Processes of Palaeolithic Site Formation: an Experimental Study (Unpublished PhD). University of California.

Serangeli, J., Böhner, U., Van Kolfschoten, T., Conard, N.J., 2015. Overview and new results from large-scale excavations in Schöningen. J. Hum. Evol. 89, 27-45. https:// doi.org/10.1016/j.jhevol.2015.09.013.

Serangeli, J., Rodríguez-Alvarez, B., Tucci, M., Verheijen, I., Bigga, G., Böhner, U., Urban, B., Van Kolfschoten, T., Conard, N.J., 2018. The Project Schöningen from an ecological and cultural perspective. Quat. Sci. Rev. 198, 140-155.

Speth, J.D., 2017. Putrid meat and fish in the Eurasian middle and upper paleolithic: are we missing a key part of neanderthal and modern human diet? PaleoAnthropology 2017, 44-72.

Stahlschmidt, M.C., Miller, C.E., Ligouis, B., Goldberg, P., Berna, F., Urban, B., Conard, N.J., 2015. The depositional environments of Schöningen 13 II-4 and their archaeological implications. J. Hum. Evol. 89, 71-91. https://doi.org/10.1016/j. jhevol.2015.07.008.

Starkovich, B.M., Conard, N.J., 2015. Bone taphonomy of the Schöningen 'Spear Horizon South' and its implications for site formation and hominin meat provisioning. J. Hum. Evol. 89, 154-171. https://doi.org/10.1016/j.jhevol.2015.09.015.

Thacher, D., Milne, S.B., Park, R., 2017. Applying GIS and statistical analysis to assess the correlation of human behaviour and ephemeral architectural features among PalaeoEskimo sites on Southern Baffin Island. Nunavut. J. Archaeol. Sci. Rep. 14, 21-30. https://doi.org/10.1016/j.jasrep.2017.05.004.

Thayer Morton, A.G., 1995. Archaeological Site Formation: Experiments in Lake Margin Processes. University of Cambridge, Unpublished PhD.

Thieme, H., 1997. Lower Palaeolithic hunting spears from Germany. Nature 385, 807-810. https://doi.org/10.1038/385807a0.

Thieme, H., 2005. The lower palaeolithic art of hunting: the case of Schöningen 13II-4, lower Saxony, Germany. In: Gamble, C., Porr, M. (Eds.), The Hominid Individual in Context: Archaeological Investigations of Lower and Middle Palaeolithic Landscapes, Locales and Artefacts. Routledge, London, pp. 115-132.

Thieme, H., 2007. Überlegungen zum Gesamtbefund des Wildpferd-Jagdlagers. Theiss: Stuttgart. In: Thieme, H. (Ed.), Die Schöninger Speere - Mensch und Jagd vor 400.000 Jahren, pp. 177-190.

Urban, B., 2007. Interglacial pollen records from Schöningen, north Germany. In: Sirocko, F., Claussen, M., Sánchez Goñi, M.F., Litt, T. (Eds.), The Climate of Past Interglacials. Elsevier, Amsterdam, pp. 417-444.

Uthmeier, T., Chabai, V., 2018. Formation processes at sites with high-resolution sequences in the Crimean Middle Paleolithic: the Kabazi V rock shelter and the openair site of Kabazi II compared. Quat. Int. 485, 44-67. https://doi.org/10.1016/j. quaint.2018.01.017.

Van Kolfschoten, T., 2012. Schöningen: the history and results of 20 years archaeozoological research. Analecta Praehist. Leidensia 43/44, 371-386.

Van Kolfschoten, T., 2014. The Palaeolithic locality Schöningen (Germany): a review of the mammalian record. Quat. Int. 326-327, 469-480. https://doi.org/10.1016/j. quaint.2013.11.006.

Van Kolfschoten, T., Buhrs, E., Verheijen, I., 2015. The larger mammal fauna from the Lower Paleolithic Schöningen Spear site and its contribution to hominin subsistence. J. Hum. Evol. 89, 138-153. https://doi.org/10.1016/j.jhevol.2015.09.014.

Van Kolfschoten, T., Parfitt, S.A., Serangeli, J., Bello, S.M., 2015. Lower paleolithic bone tools from the 'spear Horizon' at Schöningen (Germany). J. Hum. Evol. 89, 226-263. https://doi.org/10.1016/j.jhevol.2015.09.012.

Voormolen, B., 2008. Ancient Hunters, Modern Butchers. Schöningen 13II-4, a KillButchery Site Dating from the Northwest European Lower Palaeolithic (Unpublished PhD). Leiden University.

Wansleeben, M., 2017. A Visual Spatial Analysis of Stone Age Sites. Analecta Praehist. Leiden, vol. 47, pp. 11-18.

Watson, G.S., 1961. Goodness-of-fit tests on a circle. Biometrika 48 (1/2), 109-114.

Yong Technology Inc., 2014. Online Rose Diagram. http://www.yongtechnology.com/ yong-lab/online-rose-diagram/. 